\title{
124. Inhibitory Effect Elicited by Pretreatment with Attenuated Ehrlich Ascites Tumor Cells toward the Same Tumor
}

\author{
By Masahisa Kushibe, Osamu Ochi, Hayato Kuwabara, \\ and Kazuyuki MaEKAwA \\ Faculty of Agriculture and Department of Science, \\ Ehime University
}

(Comm. by Yuzuru OkUDA, M.J.A., June 12, 1968)

When a complex of a fraction of RNA isolated from Ehrlich ascites tumor (RNA) with methylated bovine serum albumin (MA) had been injected into the abdominal cavity at certain intervals, the incidence of tumor cells was markedly inhibited, and above $60 \%$ of treated mice were not taken ill.1) It was already reported that animals immunized with tumor cells attenuated through some treatments such as irradiation with ${ }^{\circ 0} \mathrm{Co}$, treatment with nitrogen-mustard $\mathrm{N}$-oxide, incubation with RNA, DNA acquired resistance toward the tumor. ${ }^{2)-7)}$

The authors found two facts:8) (a) If tumor cells were incubated in vitro with MA only or with MA-RNA for a short time, the tumor cells became inactive; (b) Mice rescued from the incidence of tumor cells by treatment with MA-RNA developed a resistance toward reinoculation of tumor cells. Hence, mice were now immunized with the cells attenuated beforehand by treating with MA-RNA so as to be able to scrutinize effects for the incidence of tumor.

Experimental. As shown in Table I, the mice (ddT) were divided into 4 groups, in which mice of $\mathrm{A}, \mathrm{B}$, and $\mathrm{C}$ groups were

Table I. Pretreatment and survival days after 1st treatment

\begin{tabular}{c|cc|c|c}
\hline \multirow{2}{*}{ Group } & \multicolumn{2}{|c|}{ Dose for immunization } & \multirow{2}{*}{ No. of mice** } & \multirow{2}{*}{$\begin{array}{c}\text { Mean survival } \\
\text { days }\end{array}$} \\
\cline { 2 - 3 } & No. of cells & MA-RNA* & & $>29$ \\
A & $10^{5}$ & $0.2 \mathrm{ml}$ & 8 & $\prime \prime$ \\
B & $\prime \prime$ & 0.4 & 8 & $\prime \prime$ \\
C & $\prime \prime$ & 0.6 & 8 & 10 \\
\hline control & $\prime \prime$ & saline $0.2 \mathrm{ml}$ & 8 & \\
\hline
\end{tabular}

* $15 \mathrm{mg} \mathrm{MA}+5 \mathrm{mg} \mathrm{RNA} / \mathrm{ml}$.

*** 古: 우 $=1: 1$. 
injected abdominally with a mixed suspension of tumor cells $\left(10^{5}\right)$ suspended into $0.2 \mathrm{ml}$ of ascites and $0.2,0.4$, and $0.6 \mathrm{ml}$ of MA-RNA suspension $^{1)}(15 \mathrm{mg}+5 \mathrm{mg} / \mathrm{ml})$ respectively, after being incubated for 2-3 minutes at $25^{\circ} \mathrm{C}$. While a control group inoculated with cells alone all developed tumors and were dead after 8-12 days (mean 10 days), mice of $\mathrm{A}, \mathrm{B}$, and $\mathrm{C}$ groups all appeared to be healthy. After 29 days elapsed, tumor cells $\left(10^{5}\right)$ were inoculated as a challenge to the mice of groups $\mathrm{A}, \mathrm{B}$, and $\mathrm{C}$ and another new control group was set up. The resulting evidence shows that the mortality of the immunized group is low, and when the ratio of MA-RNA: tumor cells is lower, the mortality is particularly lower. Therefore, it seems to be an important factor that the attenuation is not excessive. The surviving mice were dissected after 6 months to study the aspects of tumor cells. However there were none.

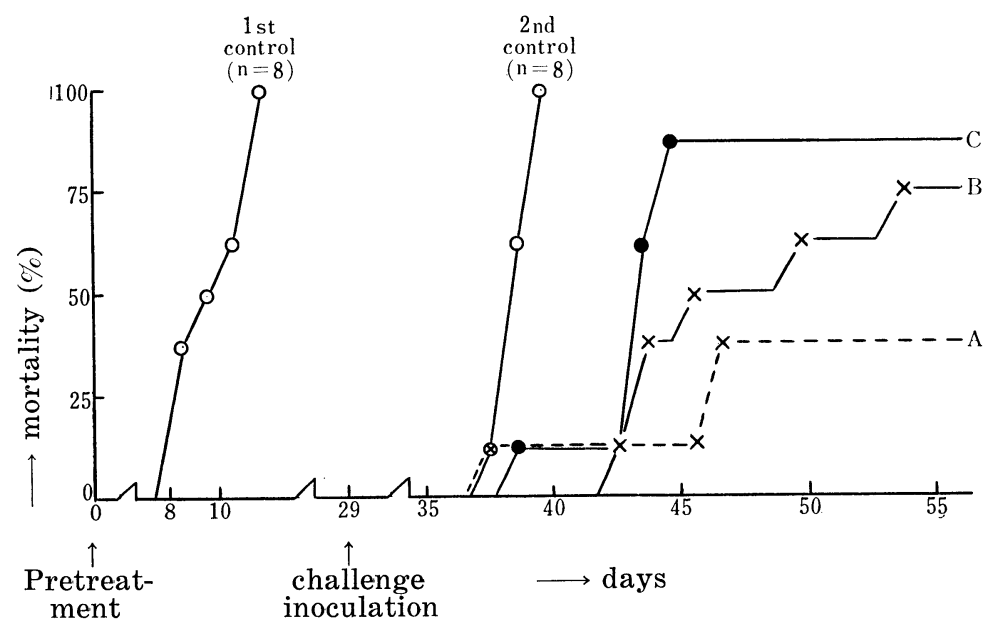

Fig. 1. Effect of pre-immunization for challenge inoculation. $\mathrm{A}, \mathrm{B}, \mathrm{C}$ refer to Table I.

As a second approach, the pretreatment was carried out twice. That is, $0.3 \mathrm{ml}$ of MA-RNA suspension (same conc. as mentioned above) and tumor cells $\left(10^{5} / 0.2 \mathrm{ml}\right)$ were mixed throughly at $5^{\circ} \mathrm{C}$ and injected immediately into the abdominal cavity of mice ( $\hat{\circ} 6$, 우 6) (group D). Group $\mathrm{E}$ was treated with MA solution alone (15 $\mathrm{mg} / \mathrm{ml}$, in physiological saline solution), instead of MA-RNA. The 1st control group was inoculated with tumor cells $\left(10^{5}\right)$ only. In 16 days after 1st treatment, mice were treated in the same manner and with the same mixed suspension (with freshly prepared cells) as described before, using 3 mice as 2nd control. Thirty days after, $10^{5}$ of tumor cells were inoculated into the abdominal cavity of the 


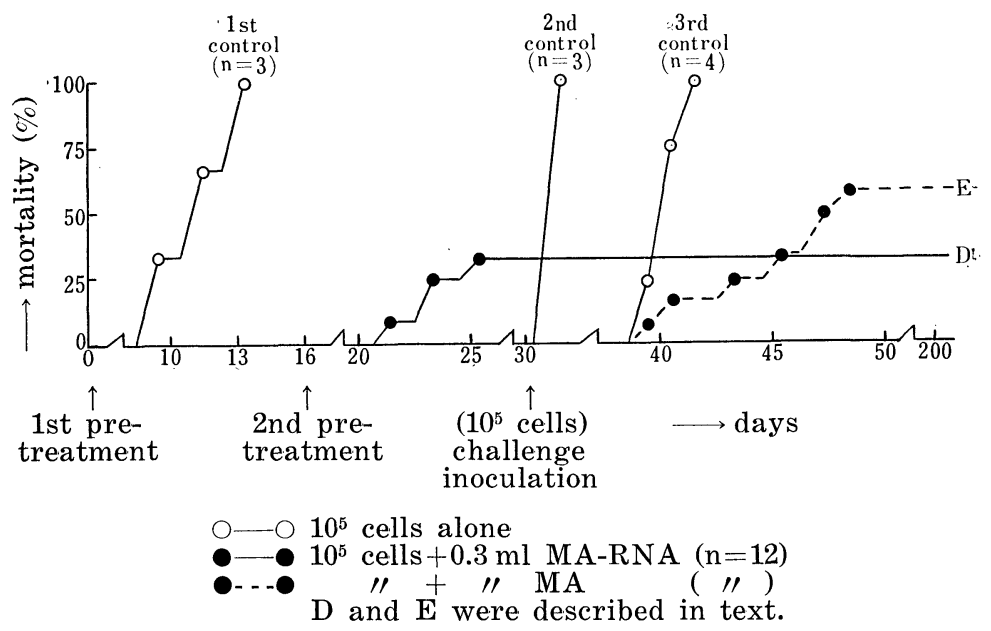

Fig. 2. Effect of repeated pretreatment for challenge inoculation.

pretreated mice and control mice were newly set up as the challenge.

As seen from Fig. 2, all of the mice of group D survived, while all mice belonging to the control group developed tumors and died.

About $40 \%$ of the mice belonging to group $\mathrm{E}$ also did not develop tumors. This may be ascribed to the fact that an anti-tumor factor would be elicited by the repeated treatment with considerably attenuated cells resulting from the MA treatment.

As indicated in Figs. 3 and 4 (photographs of electronmicroscope), it seems that the MA had a stronger effect than MA-RNA upon the tumor cells. Meanwhile, to elicit the effective factor in the mice was impossible, by applying the tumor cells treated under a more drastic condition. That is, a suspension of tumor cells in the Ringer's solution (1:1) was subjected to repeated freezing and thawing 5 times, and then injected into the abdominal cavity of mice 6 times at intervals of 3 days $(0.25 \mathrm{ml} \times 6)$. In one week after last injection, $10^{5}$ tumor cells were inoculated. But, results were the same in both control and treated mice.

It is difficult to elicit any effective factor by applying drastically damaged cells. Thus, by means of immunization with the tumor cells inactivated properly, an anti-tumor factor would be elicited in the body.

As regards this factor, it can be considered that cellular immunization might be evoked by inactivated cells or interferon formation might be stimulated by cells treated with MA-RNA, as elicited by polyamine. ${ }^{9)-12)}$ 


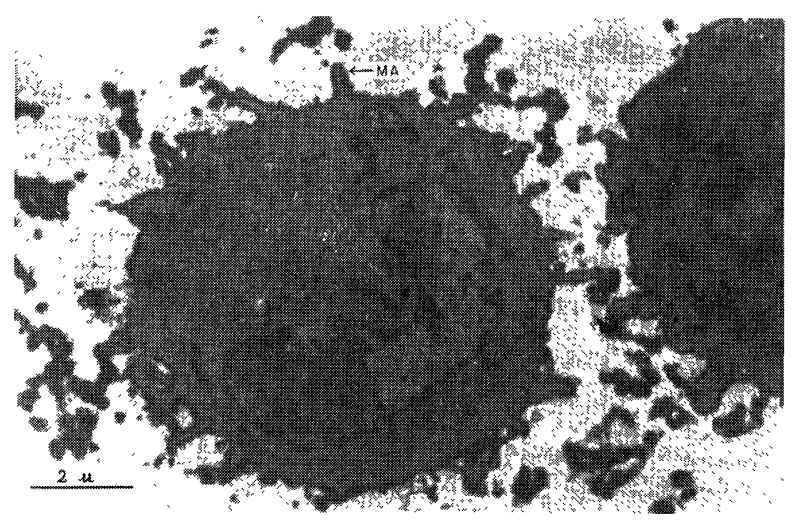

Fig. 3-a. MA treated Ehrlich ascites tumor cells. The photographs (Figs. 4-a and b) show that MA is deposited on the surface of the cell.

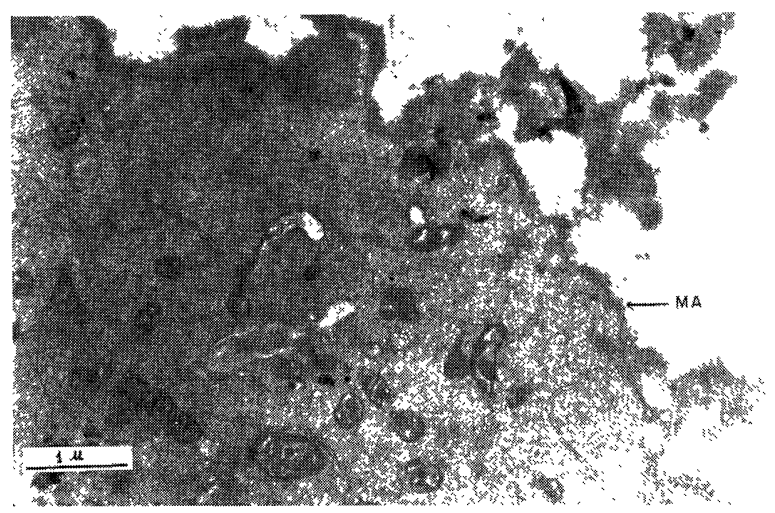

Fig. 3-b. MA treated Ehrlich ascites tumor cells.

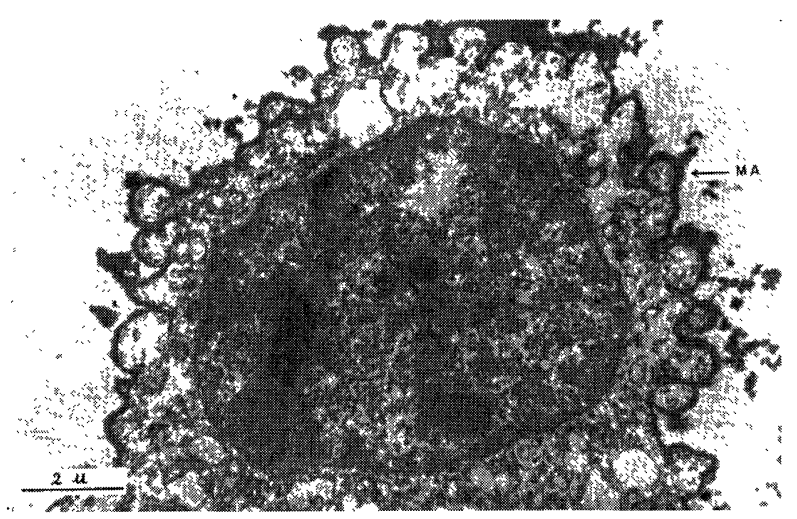

Fig. 3-c. MA treated Ehrlich ascites tumor cells. Damage to treated tumor cell after time elapsed $\left(37^{\circ} \mathrm{C}\right.$, 25 min.). 


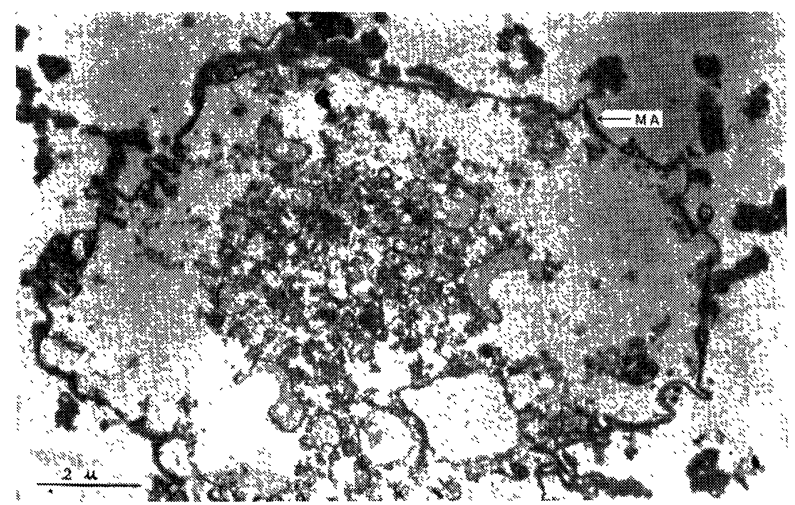

Fig. 3-d. MA treated Ehrlich ascites tumor cells. Radical damage to treated. cells after time elapsed $\left(37^{\circ} \mathrm{C}\right.$, 40 min.).

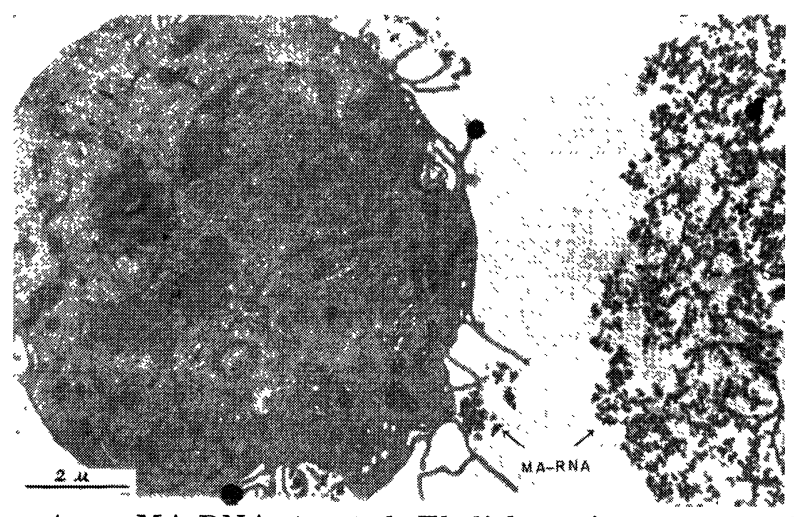

Fig. 4-a. MA-RNA treated Ehrlich ascites tumor cells. The photograph shows that MA-RNA is taking in tumor cell.

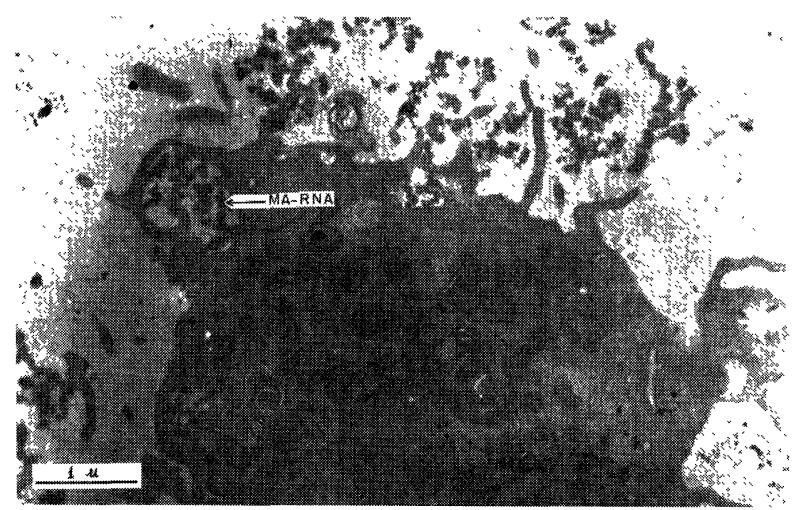

Fig. 4-b. MA-RNA treated Ehrlich ascites tumor cells. This photograph also shows the MA-RNA has been taken into tumor cell. 


\section{References}

1) K. Maekawa and M. Kushibe: Proc. Japan Acad., 43, 224 (1967).

2) M. Ishidate, Y. Hashimoto, S. Odashima, and H. Sudo: Gann, 56, 13 (1965).

3) M. Ishidate: Gann, 58, 5 (1967).

4) J. C. Gazet and B. McKibbin: J. Surg. Res., 5, 35 (1965).

5) S. Esposito: Nature, 203, 1078 (1964).

6) J. L. Glick and A. R. Goldberg: Sci., 149, 997 (1965).

7) J. L. Glick: Cancer Res., 27, 175 (1967).

8) K. Maekawa and Kushibe: Abstract (No. 5092) of Annual Meeting of Agric. Chem. Soc. of Japan (1968).

9) A. Isaces, R. A. Cox, and Z. Rotens: Lancet, 113 (1963-II).

10) G. P. Lampson, A. A. Tytell, A. K. Field, M. M. Nemes, and M. R. Hilleman: Proc. Nat. Acad. Sci., 5\&, 782 (1967).

11) A. K. Field, A. A. Tytell, G. P. Lampson, and M. R. Hilleman: Ibid., 58, 1004 (1967).

12) T. C. Merigan: Nature, 214, 416 (1967). 